\title{
sciendo
}

Current Issues in Pharmacy and Medical Sciences

Formerly ANNALES UNIVERSITATIS MARIAE CURIE-SKLODOWSKA, SECTIO DDD, PHARMACIA

journal homepage: http://www.curipms.umlub.pl/

\section{Pathogen profile of urinary tract infections in Nephrology Unit}

\author{
Dariusz Chojeta ${ }^{1}$, Iwona Smarz-Widelska ${ }^{2}$, Malgorzata M. KozIol $^{1 \star}$ \\ ${ }^{1}$ Chair and Department of Medical Microbiology, Medical University of Lublin, Lublin, Poland \\ 2 Department of Nephrology, Cardinal Stefan Wyszynski Provincial Hospital, Lublin, Poland
}

\section{ARTICLE INFO \\ Received 26 August 2021 \\ Accepted 18 October 2021}

\section{Keywords:}

nosocomial infection,

antibiotic resistance,

Escherichia coli.

\begin{abstract}
Introduction. Urinary tract infection (UTI) is one of the most common types of infection in both hospitalized and outpatient settings. The etiology is mostly bacterial, and the typical causative agent is uropathogenic Escherichia coli. There is a noticeable increase in drug resistance of pathogenic microorganisms.

The aim of the study was retrospective analyses of etiological agents of UTI and their antibiotic resistance patterns in Nephrology Unit patients.

Material and methods. An infection was diagnosed based on the patient's symptoms and positive results of urine culture, carried out over 26 months. The clinical material was tested by using the VITEK system, the drug susceptibility of the emerged pathogens was identified.

Results. The most common etiological agents of UTI were Gram-negative rods: Escherichia coli (51.23\%), Klebsiella spp. (19.3\%) and Proteus spp. (13.68\%). The analysis of drug resistance profiles of these pathogens showed a high percentage of strains resistant to broad-spectrum penicillins and fluoroquinolones. At the same time, it seems that E. coli isolates presented the most favorable pattern of drug susceptibility in this comparison.

Conclusions. The alarming tendency of increasing drug resistance among pathogens causing UTIs to antibiotics such as penicillins or fluoroquinolones prompts a careful choice of drugs in empirical therapies. The most appropriate practice in this regard seems to be meticulous control of nosocomial infections and making therapeutic decisions based on the knowledge of local microbiological data.
\end{abstract}

\section{INTRODUCTION}

Urinary tract infections (UTIs) are considered to be one of the most common infections both among hospitalized and outpatient patients $[1,2]$. It is estimated that they constitute about $1 / 3$ of all cases of nosocomial infections [3]. The etiology is most often bacterial (much less often fungal or viral) - definitely dominant Gram-negative rods, mainly Escherichia coli. Subsequently, bacteria of the genus Klebsiella spp., Proteus spp., Enterobacter spp., Pseudomonas spp. or Gram-positive cocci Staphylococcus saprophyticus and Enterococcus spp., are mentioned [2,4,5]. The diagnosis of infection should be based on a positive urine microbial culture, the titer of microbial growth, and the method of specimen collection, in correlation with the patient's symptoms and risk factors. The current state of knowledge has determined that the urinary tract above the level of the bladder sphincter was considered sterile, but the latest scientific research indicates the existence of a "urine microbiome". According to this hypothesis, UTI can

\footnotetext{
* Corresponding author

e-mail: malgorzata.koziol@umlub.pl
}

also be perceived as a dysbiosis of microorganisms within the bladder, and not only as the presence of a pathogenic microorganism [6]. Detection of bacteria in a significant amount exceeding $10^{5} \mathrm{CFU} / \mathrm{ml}$ does not always determine the clinical form [7] - the infection may take the form of asymptomatic bacteriuria, acute or chronic cystitis, acute or chronic pyelonephritis $[4,6]$. Many patient-dependent variables must be considered in determining the type of complications. A different classification distinguishes the division into complicated UTIs (concerning people with anatomical or functional disorders in the urinary outflow, more common in hospitalized patients and requiring longterm catheterization of the urinary bladder) and uncomplicated UTI (concerning people without such disorders, more common in outpatients) $[8,9]$.

\section{AIM}

The aim of this study was to retrospectively analyze the frequency of UTI, etiological agents, and the drug 
susceptibility profile of the most commonly cultured pathogens in Nephrology Unit patients.

\section{MATERIALS AND METHODS}

The study included patients hospitalized in the Department of Nephrology and Hypertension of the Provincial Specialist Hospital in Lublin (Poland). The observation period was 26 months (from January 2016 to February 2018). Microbiological tests results were analyzed in the indicated period. Clinical material was collected from patients with suspected infection. In general, for microbiological analysis in the Unit, the urine, blood, fragments of soft tissues, ear swabs, body cavity fluids, pus and wound materials were sent to the laboratory. The collection procedure was performed with due care and following the principles of asepsis. On this basis, infection was diagnosed in approximately $9.5 \%$ of all hospitalized patients (309 out of 3,258 people): 164 women (53.07\%) and 145 men (46.93\%).

Analysis of urine samples revealed the presence of microbes in 244 patients ( $7.5 \%$ of all hospitalized patients), and in some cases, more than one pathogen was detected in the clinical specimen as a potential etiological agent. Diagnostics and evaluation of drug susceptibility were performed with the use of automatic methods (VITEK $\AA$ system: ID, AST). The interpretation of the obtained results was carried out following the EUCAST 9.0 recommendations. The marked pattern of the antibiogram was in some cases different between individual urine samples containing pathogens of the same species/genus.

\section{RESULTS}

\section{Types of infections}

The analysis of the location from which clinical materials were collected for microbiological tests allowed to determine the frequency of occurrence of particular types of infections in the patients of the Unit (Figure 1). Urinary tract infections (UTIs), found in 244 patients (78.96\% of all patients with confirmed infection), dominated over bloodstream infections/ bacteremia (BSIs; 97 patients - 31.39\%) and soft tissue infections (STIs; 18 patients $-5.82 \%$ ).

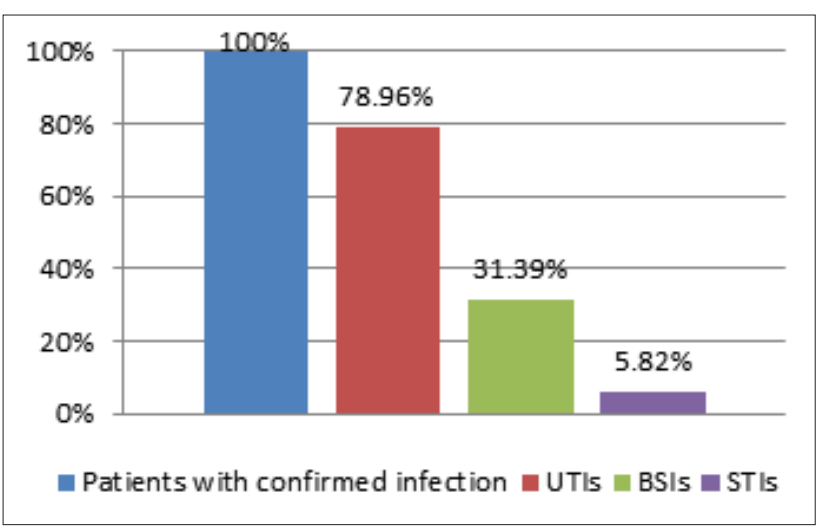

Figure 1. Types of infections in Nephrology Unit patients

\section{Etiological agents of UTIs}

The study also focused on the species and types of pathogens detected in the urine (Table 1). A total of 285 microorganisms were isolated in the collected samples of clinical material. A clear predominance of Gram-negative rods from the Enterobacteriaceae family as etiological factors of the UTI was found - Escherichia coli, Klebsiella spp. and Proteus spp. bacteria (together constituting 84.21\% of all isolates). In the group of women, the percentage of $E$. coli cases was almost twice as high as that of men $(65.22 \%$ vs. $33.06 \%)$.

Table 1. Ethiological agents of UTIs

\begin{tabular}{|l|c|c|c|c|c|c|}
\hline \multicolumn{1}{|c|}{ Pathogen } & Men & {$[\%]$} & Women & {$[\%]$} & Total & {$[\%]$} \\
\hline Escherichia coli & 41 & 33.06 & 105 & 65.22 & 146 & 51.23 \\
\hline Klebsiella spp. & 34 & 27.42 & 21 & 13.04 & 55 & 19.30 \\
\hline Proteus spp. & 18 & 14.52 & 21 & 13.04 & 39 & 13.68 \\
\hline Enterococcus spp. & 10 & 8.06 & 3 & 1.86 & 13 & 4.56 \\
\hline Pseudomonas spp. & 7 & 5.65 & 2 & 1,24 & 9 & 3.16 \\
\hline Enterobacter spp. & 4 & 3.23 & 3 & 1,86 & 7 & 2.46 \\
\hline Acinetobacter spp. & 3 & 2.42 & 0 & 0 & 3 & 1.05 \\
\hline Others & 7 & 5.65 & 6 & 3.73 & 13 & 4.56 \\
\hline Total & 124 & 100 & 161 & 100 & 285 & 100 \\
\hline
\end{tabular}

\section{Drug resistance profile of Escherichia coli}

Patterns of drug resistance have been developed for the 3 most common UTI etiological agents found in the urine samples. During the observation period, 146 diverse E. coli strains were isolated (Table 2). As previously mentioned, the profiles of the antibiograms determined could differ between the isolated bacteria, hence the variable number of strains for which the degree of susceptibility was not determined for a particular drug (column "N" in Table 2, Table 3, and Table 4). The percentages given in the tables for each category are calculated concerning the total number of isolates for which a pattern of resistance to a given antibiotic has been determined (same in Table 2, Table 3, and Table 4).

The highest percentage of susceptible $E$. coli strains was found to be to the following antibiotics: all marked from the carbapenem group (100\%), tigecycline (100\%), colistin (100\%), ceftriaxone $(94.66 \%)$, piperacillin/tazobactam (93.84\%). However, the highest degree of drug resistance was observed to: ampicillin (69.57\%), norfloxacin $(51.11 \%)$, amoxicillin/clavulanic acid (34.48\%), and ciprofloxacin $(34.25 \%)$.

\section{Drug resistance profile of Klebsiella spp.}

During the reporting period, 55 infections with Klebsiella spp. were detected (Table 3), among them, the dominant species was Klebsiella pneumoniae.

The highest percentage of susceptible strains was found to be to the following antibiotics: colistin (100\%), all marked from the carbapenem group (97.62-100\%), gentamicin (67.27\%) and ceftriaxone (66.67\%). The highest degree of drug resistance was observed to: ampicillin (100\%), ciprofloxacin $(67.27 \%)$, tobramycin $(62.50 \%)$, and amoxicillin/ clavulanic acid $(62.26 \%)$. 
Table 2. Drug resistance profile of Escherichia coli

\begin{tabular}{|l|c|c|c|c|}
\hline \multirow{2}{*}{ Antibiotic } & \multicolumn{5}{|c}{ The number of strains } \\
\cline { 2 - 5 } & $\mathrm{S}$ & $\mathrm{I}$ & $\mathrm{R}$ & $\mathrm{N}$ \\
\hline Ampicillin & $14(30.43 \%)$ & - & $32(69.57 \%)$ & $100(68.49 \%)$ \\
\hline $\begin{array}{l}\text { Piperacillin/ } \\
\text { Tazobactam } \\
\text { Amoxicillin/ } \\
\text { Clavulanic acid }\end{array}$ & $137(93.84 \%)$ & $1(0,68 \%)$ & $8(5.48 \%)$ & - \\
\hline Cephalexin & $38(84.44 \%)$ & - & $7(15.56 \%)$ & $101(69.17 \%)$ \\
\hline Cefuroxime & $116(79.45 \%)$ & - & $30(20.55 \%)$ & - \\
\hline Ceftazidime & $129(88.36 \%)$ & - & $17(11.64 \%)$ & - \\
\hline Cefotaxime & $127(86.99 \%)$ & - & $19(13.01 \%)$ & - \\
\hline Ceftriaxone & $124(94.66 \%)$ & - & $7(5.34 \%)$ & $15(10 \%)$ \\
\hline Cefepime & $129(88,36 \%)$ & $6(4,11 \%)$ & $11(7.53 \%)$ & - \\
\hline Meropenem & $146(100 \%)$ & - & - & - \\
\hline Imipenem & $101(100 \%)$ & - & - & $45(30.82 \%)$ \\
\hline Ertapenem & $57(100 \%)$ & - & - & $89(60.95 \%)$ \\
\hline Gentamicin & $130(89.04 \%)$ & - & $16(10.96 \%)$ & - \\
\hline Amikacin & $136(93.15 \%)$ & $9(6,16 \%)$ & $1(0.68 \%)$ & - \\
\hline Tobramycin & $88(87.13 \%)$ & - & $13(12.87 \%)$ & $45(30.82 \%)$ \\
\hline Ciprofloxacin & $96(65.75 \%)$ & - & $50(34.25 \%)$ & - \\
\hline Norfloxacin & $22(48.89 \%)$ & - & $23(51.11 \%)$ & $101(69.17 \%)$ \\
\hline $\begin{array}{l}\text { Trimetoprim/ } \\
\text { Sulfamethoxazole }\end{array}$ & $101(69.18 \%)$ & - & $45(30.82 \%)$ & - \\
\hline Nitrofurantoin & $40(90.91 \%)$ & - & $4(9.09 \%)$ & $102(69.86 \%)$ \\
\hline Tigecycline & $101(100 \%)$ & - & - & $45(30.82 \%)$ \\
\hline Colistin & $95(100 \%)$ & - & - & $51(34.93 \%)$ \\
\hline
\end{tabular}

List of shortcuts: $\mathbf{S}$ - sensitive, standard dosage regimen; I - increased exposure; $\mathbf{R}$ - resistant; $\mathbf{N}$ - strains for which the degree of susceptibility was not determined

Table 3. Drug resistance profile of Klebsiella spp.

\begin{tabular}{|c|c|c|c|c|}
\hline \multirow{2}{*}{ Antibiotic } & \multicolumn{4}{|c|}{ The number of strains } \\
\hline & S & I & $\mathrm{R}$ & $\mathrm{N}$ \\
\hline Ampicilin & - & - & $11(100 \%)$ & $44(80 \%)$ \\
\hline $\begin{array}{l}\text { Piperacillin/ } \\
\text { Tazobactam }\end{array}$ & $23(41.82 \%)$ & $1(1.82 \%)$ & $31(56.36 \%)$ & - \\
\hline $\begin{array}{l}\text { Amoxicillin/ } \\
\text { Clavulanic acid }\end{array}$ & $20(37.74 \%)$ & - & $33(62.26 \%)$ & $2(3.63 \%)$ \\
\hline Cephalexin & $5(38.46 \%)$ & - & $8(61.54 \%)$ & $42(76.36 \%)$ \\
\hline Cefuroxime & $22(40.00 \%)$ & - & $33(60.00 \%)$ & - \\
\hline Ceftazidime & $26(47.27 \%)$ & $1(1.82 \%)$ & $28(50.91 \%)$ & - \\
\hline Cefotaxime & $23(41.82 \%)$ & - & $32(58.18 \%)$ & - \\
\hline Ceftriaxone & $24(66.67 \%)$ & - & $12(33.33 \%)$ & $19(34.54 \%)$ \\
\hline Cefepime & $26(47.27 \%)$ & - & $29(52.73 \%)$ & - \\
\hline Meropenem & $54(98.18 \%)$ & - & $1(1.82 \%)$ & - \\
\hline Imipenem & $41(97.62 \%)$ & $1(2.38 \%)$ & - & $13(23.63 \%)$ \\
\hline Ertapenem & $23(100 \%)$ & - & - & $32(58.18 \%)$ \\
\hline Gentamicin & $37(67.27 \%)$ & - & $18(32.73 \%)$ & - \\
\hline Amikacin & $27(49.09 \%)$ & $28(50.91 \%)$ & - & - \\
\hline Tobramycin & $9(37.50 \%)$ & - & $15(62.50 \%)$ & $31(56.36 \%)$ \\
\hline Ciprofloxacin & $16(29.09 \%)$ & $2(3.64 \%)$ & $37(67.27 \%)$ & - \\
\hline Norfloxacin & $5(38.46 \%)$ & - & $8(61.54 \%)$ & $42(76.36 \%)$ \\
\hline \begin{tabular}{|l} 
Trimetoprim/ \\
Sulfamethoxazole \\
\end{tabular} & $29(52.73 \%)$ & $1(1.82 \%)$ & $25(45.45 \%)$ & - \\
\hline Tigecycline & $21(51.22 \%)$ & $10(24.39 \%)$ & $10(24.39 \%)$ & $14(25.45 \%)$ \\
\hline Colistin & $36(100 \%)$ & - & - & $19(34.54 \%)$ \\
\hline
\end{tabular}

S - sensitive, standard dosage regimen; I - sensitive, increased exposure; $\mathrm{R}$ - resistant; $\mathrm{N}$ - strains for which the degree of susceptibility was not determined
Table 4. Drug resistance profile of Proteus spp.

\begin{tabular}{|l|c|c|c|c|}
\hline \multirow{2}{*}{ Antibiotic } & \multicolumn{5}{|c|}{ The number of strains } \\
\cline { 2 - 5 } & $\mathrm{S}$ & $\mathrm{I}$ & $\mathrm{R}$ & $\mathrm{N}$ \\
\hline Ampicilin & $5(62.5 \%)$ & - & $3(37.5 \%)$ & $31(79.48 \%)$ \\
\hline $\begin{array}{l}\text { Piperacillin/ } \\
\text { Tazobactam }\end{array}$ & $36(94.74 \%)$ & - & $2(5.26 \%)$ & $1(2.56 \%)$ \\
\hline $\begin{array}{l}\text { Amoxicillin/ } \\
\text { Clavulanic acid }\end{array}$ & $29(74.36 \%)$ & - & $10(25.64 \%)$ & - \\
\hline Cephalexine & $5(62.5 \%)$ & - & $3(37.5 \%)$ & $31(79.48 \%)$ \\
\hline Cefuroxime & $27(69.23 \%)$ & - & $12(30.77 \%)$ & - \\
\hline Ceftazidime & $32(82.05 \%)$ & $4(10.6 \%)$ & $3(7.69 \%)$ & - \\
\hline Cefotaxime & $28(71.79 \%)$ & - & $11(28.21 \%)$ & - \\
\hline Ceftriaxone & $28(90.32 \%)$ & - & $3(9.68 \%)$ & $8(20.51 \%)$ \\
\hline Cefepime & $29(74.36 \%)$ & $3(7.69 \%)$ & $7(17.95 \%)$ & - \\
\hline Meropenem & $39(100 \%)$ & - & - & - \\
\hline Imipenem & $24(77.42 \%)$ & $7(22.58 \%)$ & - & $8(20.51 \%)$ \\
\hline Ertapenem & $14(100 \%)$ & - & - & $25(64.1 \%)$ \\
\hline Gentamicin & $26(66.67 \%)$ & $1(2.56 \%)$ & $12(30.77 \%)$ & - \\
\hline Amikacin & $32(82.05 \%)$ & $1(2.56 \%)$ & $6(15.38 \%)$ & - \\
\hline Tobramycin & $22(70.97 \%)$ & - & $9(29.03 \%)$ & $8(20.51 \%)$ \\
\hline Ciprofloxacin & $17(43.59 \%)$ & $6(15.38 \%)$ & $16(41.03 \%)$ & - \\
\hline Norfloxacin & $4(50.00 \%)$ & - & $4(50.00 \%)$ & $31(79.48 \%)$ \\
\hline $\begin{array}{l}\text { Trimetoprim/ } \\
\text { Sulfamethoxazole }\end{array}$ & $20(51.28 \%)$ & - & $19(48.72 \%)$ & - \\
\hline Tigecycline & $1(5.26 \%)$ & $1(5.26 \%)$ & $17(89.47 \%)$ & $20(51.28 \%)$ \\
\hline Colistin & - & - & $14(100 \%)$ & $25(64.1 \%)$ \\
\hline S sensive & - & - & - & - \\
\hline
\end{tabular}

S - sensitive, standard dosage regimen; I - sensitive, increased exposure; $\mathrm{R}$ - resistant; $\mathrm{N}$ - strains for which the degree of susceptibility was not determined

\section{Drug resistance profile of Proteus spp.}

During the reporting period, 39 pathogens of the genus Proteus spp. were detected. (Table 4), among them, the species Proteus mirabilis dominated.

The highest percentage of susceptible strains was found to be to the following antibiotics: meropenem $(100 \%)$, ertapenem (100\%), piperacillin/azobactam $(94.74 \%)$ and ceftriaxone $(90.32 \%)$. The highest degree of drug resistance was observed in: colistin (100\%), tigecycline $(89.47 \%)$ and norfloxaicin $(50.00 \%)$.

\section{DISCUSSION}

Our study confirmed that UTI is a common type of infection found in hospital conditions. The percentage of this infection type turned out to be significantly higher than indicated by the scientific data quoted in the introduction (UTI as $1 / 3$ of nosocomial infections) [3], but this should be considered as a result of a specific group of patients from the Nephrology Unit. Hospitalized individuals are often undergoing dialysis treatment and are burdened with multiple UTIs risk factors such as female gender, diabetes, obesity, anatomical and functional disorders in the urinary outflow, history of previous UTIs, history of urological, and gynecological procedures $[4,10]$. Moreover, during a hospital stay, the requirement for long-term use of urinary catheters becomes a very important risk factor for many serious complications [3].

When analyzing more broadly the topic of nosocomial infections, it should be realized that an unambiguous 
determination of the out-of-hospital or in-hospital origin of infection can be very difficult, sometimes even impossible [11]. The risk of infectious complications during hospitalization consists of many factors (not always modifiable) depending on the hospital infrastructure, medical staff, medical procedures performed, and depending on the patient [12]. It follows that the risk of nosocomial infection, as well as its type and the most common etiological agents of infection and their drug resistance, may significantly differ between hospitals and hospitals units. It should be noted that this outcome is related to the specificity of the department, the patient's clinical condition, and the scope of medical procedures performed (especially invasive ones) [13]. The indicated aspects generating the potential diversity of the pathogens, as well as possibly influencing the differences in the patterns of bacterial drug resistance, encourage individual administration and scrupulous conduct of infection control programs and antibiotic management programs in each hospital ward that are based on the latest treatment guidelines and recommendations [14]. It is also worth taking actions aimed at preventing the occurrence of nosocomial infections, such as: interrupting pathogen transmission routes from medical personnel (especially through appropriate hand hygiene), and the environment, and proper management of medical waste [14].

When comparing the drug resistance profiles of the pathogens included in the study, it can be seen that E. coli seems to show the most favorable pattern of antibiotic susceptibility. There are a high percentage of cephalosporinsensitive strains (for example, cefuroxime from $2^{\text {nd }}$ generation $-79,45 \%$ ), compared to Klebsiella spp. (percentage of cefuroxime sensitive strains - 40\%) and compared to Proteus spp. $(69,23 \%)$. The profile of drug susceptibility to antibiotics from the aminoglycoside and fluoroquinolone groups is similar - in the overall summary of these 3 pathogens, E. coli is the most favorable in terms of percentages of susceptible strains. High sensitivity to carbapenems has been demonstrated for all of the bacteria indicated. Nevertheless, it should be taken into account that carbapenems are one of the strongest antibiotics currently used in medicine and are administered primarily for the treatment of infections caused by multi-drug-resistant pathogens [9].

When discussing drug resistance of pathogens, it should be noted that this problem has grown to a global scale in recent years, and it is no different from bacteria that cause UTIs $[2,9,15]$. The problem was caused by excessive and/ or irrational antibiotic use $[16,17]$. This led to the selection of strains with new, acquired resistance mechanisms transmitted between bacteria via plasmids [18]. The likely risk factors for the occurrence of multi-drug-resistant pathogens (MDR) of UTIs are the earlier use of antibiotics during the previous year and catheterization of the urinary bladder [19], and for complicated UTI, also male sex and the occurrence of UTI during the previous year [9].

The collective analysis of our studies has shown a worrying tendency to increase resistance to antibiotics such as that to beta-lactams (broad-spectrum penicillins, some cephalosporins) and fluoroquinolones. Similar patterns of drug resistance have been demonstrated in many scientific studies - for E. coli and K. pneumoniae causing complicated
UTI [20], E. coli causing uncomplicated UTI [21], and MDR strains of $E$. coli $[15]$. The cited studies also indicate the high effectiveness of fosfomycin and nitrofurantoin as first-line therapy, discouraging the use of cotrimoxazole and fluoroquinolones for this purpose [15,21]. According to the data presented above, there is a discussion about the appropriate choice of empirical therapy from among the options included in the treatment recommendations for UTIs. The most rational approach seems to be the selection of a drug adapted to local microbiological data and commonly detected uropathogens $[22,23]$. Also, the choice of empirical antibiotic therapy should be considered individually for each patient and constantly controlled [15,23].

In recent years, scientists have suggested the direction of scientific development in the diagnostics and treatment of UTIs. The researchers are dictated by the increasing pathogens drug resistance to commonly used antibiotics and the problem of recurrent infections [2,6]. In the field of diagnostics, attempts are made to search for biomarkers that would allow supplementing the standard microbiological testing. Nevertheless, Masajtis-Zagajewska A. and Nowicki M., upon analyzing the data on many potential markers (such as leukocyte esterase or interleukins), indicate that there is currently no sufficiently strong scientific evidence that would allow the introduction of determinations of these biomarkers into routine clinical practice [24]. The future in the treatment of UTI caused by uropathogenic strains of $E$. coli may be molecular drugs targeting surface adhesion factors (facilitating the binding of bacteria to the urinary tract epithelium) or virulence factors [6]. The search for appropriate antigenic patterns against which a vaccine could be developed is also in progress [6]. Nevertheless, despite the identification of potential molecular targets, the current scientific research has not allowed for the development of an effective vaccine [2]. A very promising alternative and complement to antimicrobial drugs, especially in the face of increasing MDR pathogens, seems to be phage therapy with the use of bacteriophages that destroy only bacterial cells in a highly specific manner $[25,26]$. All the above-described innovative solutions in the diagnosis and/or treatment of UTIs require further, extensive research.

\section{CONCLUSIONS}

Urinary tract infections are the most common type of infection in patients of the Nephrology Unit. In the aspect of nosocomial infections, it is worth remembering the risk factors for their occurrence and about possible preventive measures. In our study, we found a disturbingly high percentage of resistance to broad-spectrum penicillins and fluoroquinolones among the etiological factors of UTI, which may translate into the limited effectiveness of these drugs in empirical therapies. The phenomenon of increasing drug resistance of pathogens has become a global health problem in recent years, resulting from the abuse and irrational use of antibiotics. In a hospital setting, infection control programs and antibiotic management policies are strongly recommended. Awareness of the possibility of a huge variation in patterns of drug resistance of pathogens between hospital departments or geographic regions 
should encourage therapeutic decisions based on local microbiological data (so-called "hospital microbiological mapping"). Scientific evidence shows new opportunities for development in the diagnosis and/or treatment of UTIs, but more extensive research is needed prior to introducing these innovative solutions into clinical practice.

\section{ORCID iDs}

Małgorzata M. Kozioł (Dhttps://orcid.org0000-0001-9079-8594

\section{REFERNCES}

1. Gupta K, Grigoryan L, Trautner B. Urinary tract infection. Ann Intern Med. 2017;167(7):49-64.

2. Karam MRA, Habibi M, Bouzari S. Urinary tract infection: Pathogenicity, antibiotic resistance and development of effective vaccines against uropathogenic Escherichia coli. Mol Immunol. 2019;108:56-67.

3. Redder JD, Leth RA, Møller JK. Analysing risk factors for urinary tract infection based on automated monitoring of hospital-acquired infection. J Hosp Infect. 2016;92(4):397-400.

4. Foxman B. Urinary tract infection syndromes: occurrence, recurrence, bacteriology, risk factors, and disease burden. Infect Dis Clin. 2014;28(1):1-13.

5. Forsyth VS, Armbruster CE, Smith SN, Pirani A, Springman AC, Walters MS, et al. Rapid growth of uropathogenic Escherichia coli during human urinary tract infection. MBio. 2018;9(2):e00186-18.

6. McLellan LK, Hunstad DA. Urinary tract infection: pathogenesis and outlook. Trends Mol Med. 2016;22(11):946-57.

7. Smelov V, Naber K, Johansen TEB. Improved classification of urinary tract infection: future considerations. Eur Urol Suppl. 2016;15(4):71-80.

8. Mann R, Mediati DG, Duggin IG, Harry EJ, Bottomley AL. Metabolic adaptations of uropathogenic E. coli in the urinary tract. Front Cell Infect Microbiol. 2017;7:241.

9. Gomila A, Shaw E, Carratalà J, Leibovici L, Tebé C, Wiegand I, et al. Predictive factors for multidrug-resistant gram-negative bacteria among hospitalised patients with complicated urinary tract infections. Antimicrobiol Res Infect Control. 2018;7(1):1-11.

10. Mody L, Juthani-Mehta M. Urinary tract infections in older women. JAMA. 2014;311:844-54

11. Sadowska M. Dowodzenie związku przyczynowo-skutkowego w sprawach o zakażenia szpitalne. Studia Prawnicze KUL. 2017;3:107-20
12. Ziółko A. Czynniki ryzyka związane z rozpoznawaniem i zapobieganiem zakażeniom szpitalnym. Forum Zakażeń. 2016;7: 109-13.

13. Edwardson S, Cairns C. Nosocomial infections in the ICU. Anaesth Intensive Care Med. 2019;20(1):14-8.

14. Khan HA, Baig FK, Mehboob R. Nosocomial infections: Epidemiology, prevention, control and surveillance. Asian Pac J Trop Biomed. 2017;7(5):478-82.

15. Walker E, Lyman A, Gupta K, Mahoney MV, Snyder GM, Hirsch EB. Clinical management of an increasing threat: outpatient urinary tract infections due to multidrug-resistant uropathogens. Clin Infect Dis. 2016;63(7):960-5.

16. Santajit $S$, Indrawattana N. Mechanisms of antimicrobial resistance in ESKAPE pathogens. BioMed Res Int. 2016;2475067.

17. Wilson APR, Livermore DM, Otter JA, Warren RE, Jenks P, Enoch DA, et al. Prevention and control of multi-drug-resistant Gramnegative bacteria: recommendations from a Joint Working Party. J Hosp Infect. 2016;92:S1-S44.

18. Paniagua-Contreras GL, Monroy-Pérez E, Rodríguez-Moctezuma JR, Domínguez-Trejo P, Vaca-Paniagua F, Vaca S. Virulence factors, antibiotic resistance phenotypes and O-serogroups of Escherichia coli strains isolated from community-acquired urinary tract infection patients in Mexico. J Microbiol Immunol Infect. 2017;50(4):478-85.

19. Tenney J, Hudson N, Alnifaidy H, Li JTC, Fung, KH. Risk factors for aquiring multidrug-resistant organisms in urinary tract infections: a systematic literature review. Saudi Pharmaceutical J. 2018;26(5):678-84.

20. Li X, Chen Y, Gao W, Ye H, Shen Z, Wen Z, Wei J. A 6-year study of complicated urinary tract infections in southern China: prevalence, antibiotic resistance, clinical and economic outcomes. Ther Clin Risk Manag. 2017;13:1479.

21. Aguinaga A, Gil-Setas A, Alvaro A, García-Irure JJ, Navascués A. Uncomplicated urinary tract infections. Antimicrobial susceptibility study in Navarre. In Anales del Sistema Sanitario de Navarra. 2018;41(1):17-26.

22. Bollestad M, Vik I, Grude N, Blix HS, Brekke H, Lindbaek M. Bacteriology in uncomplicated urinary tract infections in Norwegian general practice from 2001-2015. BJGP Open. 2018;1(4).

23. Karam G, Chastre J, Wilcox MH, Vincent JL. Antibiotic strategies in the era of multidrug resistance. Crit Care. 2016;20(1):1-9.

24. Masajtis-Zagajewska A, Nowicki M. New markers of urinary tract infection. Clin Chim Acta. 2017;471:286-91.

25. Rohde C, Wittmann J, Kutter E. Bacteriophages: A therapy concept against multi-drug - resistant bacteria. Surg Infect. 2018;19(8):737-44.

26. Lin DM, Koskella B, Lin HC. Phage therapy: An alternative to antibiotics in the age of multi-drug resistance. World J Gastrointest Pharmacol Ther. 2017;8(3):162. 